\title{
DOCKING STUDIES ON ANTIDIABETIC MOLECULAR TARGETS OF PHYTOCHEMICAL COMPOUNDS OF SYZYGIUM CUMINI (L.) SKEELS
}

\author{
SMRUTHI G, MAHADEVAN V, VADIVEL V*, BRINDHA P
}

Centre for Advanced Research in Indian System of Medicine, School of Chemical and Biotechnology, SASTRA University, Thanjavur, Tamil Nadu, India. Email: vadivel@carism.sastra.edu

Received: 27 August 2016, Revised and Accepted: 14 September 2016

\section{ABSTRACT}

Objectives: Different parts of jamun tree (Syzygium cumini L. skeels) which belongs to the family - Myrtaceae are well-known for their antidiabetic activity. Traditional practitioners in India are using the leaf, bark, and fruits of this medicinal plant over many centuries to manage the diabetic patients. Although several research works have been conducted to prove the efficacy of this plant extracts and also to explore the active principles of this plant drug, there is no information regarding the interaction of phytoconstituents of jamun tree with diabetic targets at the molecular level. Hence, this study focused to apply a computational approach to reveal the interaction of molecules of jamun tree with antidiabetic targets.

Methods: Lamarckian genetic algorithm methodology was used for docking of 22 phytoconstituents with $\alpha$-amylase, a key enzyme that involved in carbohydrate metabolism using Autodock software.

Results: Analysis of binding energy of ligands with target receptors was remarkably lower especially for friedelin (-9.54 kcal/mol), epifriedelanol $(-8.98 \mathrm{kcal} / \mathrm{mol})$, betulinic acid $(-8.60 \mathrm{kcal} / \mathrm{mol})$, beta-sitosterol $(-8.56 \mathrm{kcal} / \mathrm{mol})$, petunidin-3-gentiobioside $(-7.52 \mathrm{kcal} / \mathrm{mol})$, kaempferol $(-7.08$ $\mathrm{kcal} / \mathrm{mol})$, petunidin $(-6.21 \mathrm{kcal} / \mathrm{mol})$, quercetin $(-6.03 \mathrm{kcal} / \mathrm{mol})$, myricetin $(-5.80 \mathrm{kcal} / \mathrm{mol})$, and bergenin $(-5.27 \mathrm{kcal} / \mathrm{mol}) \mathrm{when} \mathrm{compared} \mathrm{to}$ the synthetic drug acarbose $(-2.43 \mathrm{kcal} / \mathrm{mol})$.

Conclusion: Potential molecules identified from this study could be considered as a lead to design/synthesize anti-diabetic drug molecules in pharmaceutical industry.

Keywords: Jamun tree, Syzygium cumini, Phytochemicals, Diabetes, $\alpha$-amylase, Molecular docking.

(C) 2016 The Authors. Published by Innovare Academic Sciences Pvt Ltd. This is an open access article under the CC BY license (http://creativecommons. org/licenses/by/4. 0/) DOI: http://dx.doi.org/10.22159/ajpcr.2016.v9s3.14920

\section{INTRODUCTION}

Pancreatic $\alpha$-amylase (E.C. 3.2.1.1) is a key enzyme in the digestive system and catalyses the initial step in hydrolysis of starch to maltose and finally to glucose. Degradation of this dietary starch proceeds rapidly and leads to elevated post-prandial hyperglycemia. Human pancreatic $\alpha$-amylase in the small intestine correlates to an increase in post-prandial glucose levels, the control of which is therefore an important aspect in the treatment of diabetes [1]. Hence, retardation of starch digestion by inhibition of enzymes such as $\alpha$-amylase would play a key role in the control of diabetes. However, the discovery of specific high-affinity inhibitors of pancreatic $\alpha$-amylase for the development of therapeutics has remained elusive. Inhibitors currently in clinical use (e.g., acarbose, miglitol, and voglibose) are known to inhibit a wide range of glucosidases such as $\alpha$-glucosidase and $\alpha$-amylase. Because of their non-specificity in targeting different glucosidases, these hypoglycemic agents have their limitations and are known to produce serious side effects. Therefore, the search for safer, specific, and effective hypoglycemic agents has continued to be an important area of investigation with natural extracts from readily available traditional plant medicines offering great potential for discovery of new antidiabetic drugs [2].

While plant derivatives with purported hypoglycemic properties have been used in folk medicine and traditional healing systems, very few of these traditional anti-diabetic plants have received proper scientific scrutiny despite recommendations by the World Health Organization. Ayurveda and other Indian traditional approaches have described more than 800 plants in the Indian subcontinent, known to possess antidiabetic potential. In fact, only a few of them have been characterized for their mechanistic actions [3,4]. Syzygium cumini (L.) Skeels. (Syn: Eugenia jambolana Lam., Family: Myrtaceae) is one of the widely used plants for the treatment of diabetes by traditional practitioners over many centuries. It is commonly known as jambolan, black plum, java plum, Indian blackberry, Portuguese plum, Malabar plum, purple plum, Jamaica, and damson plum. It is a large evergreen and densely foliaceous tree with greyish-brown thick bark, exfoliating in woody scales. The wood is white; leaves are leathery, oblong-ovate to elliptic or obovate-elliptic with $6-12 \mathrm{~cm}$ long, the tip being broad and less acuminate. Flowers are scented, greenish-white, found in clusters and are round or oblong shaped in dichotomous paniculate cymes. The fruits are berries and are often obviously oblong, 1.5-3.5 cm long, darkpurple or nearly black, luscious, fleshy and edible, which contains a single large seed (Fig. 1).

Sagrawat et al. [5] reviewed the pharmacological actions and phytochemical constituents of jambolan. Various extracts of jambolan possess a range of pharmacological actions, viz., antibacterial, antifungal, antiviral, antigenotoxic, anti-inflammatory, antiulcerogenic, cardioprotective, antiallergic, anticancer, chemopreventive, radioprotective, free radical scavenging, antioxidant, hepatoprotective, antidiarrheal, hypoglycemic and antidiabetic effects [6]. Clinical and experimental studies of jambolan revealed that different parts of the plant especially fruits, seeds and stem bark possess promising antidiabetic activity. In the early 1960-1970s, some preliminary reports on the antidiabetic activity of different parts of jambolan in experimental animals have been reported [7-9].

Seeds were considered as more effective in experimental diabetes as they quickly reduced the sugar level in urine [10]. Administration of seed extracts caused hypoglycemia in mild and severe diabetic rabbits [11]. Seed methanolic extract showed inhibition in murine liver glucosidases activity [12]. Oral administration of seed extract to rats for 15 days lowered the blood glucose [13]. The ethanolic extract of seeds decreased blood sugar levels in alloxan induced diabetic rats [14]. 
Aqueous and ethanolic extract of the seeds administered orally to animals and to clinical patients at variable dose levels were found to be active [15]. Yadav et al. [16] reported that ethanol extract of seeds of jambolan in rats had a significant hypoglycemic and antihyperglycemic activity. S. cumini fruit seeds were reported to reduce blood glucose level, an increase in serum insulin level and exhibits insulinase activity [17] The antidiabetic activity of hydroalcoholic extracts of $S$. cumini seeds was reported [18]. In vitro antidiabetic activity of the ethanol extract of S. cumini seeds was investigated using $\alpha$-amylase inhibition assay [19].

The fruits are rich in citric acid, mallic acid, gallic acid, anthocyanins, delphinidin-3-gentiobioside, malvidin-3-laminaribioside, petunidin-3gentiobioside, cyaniding diglycoside, petunidin, and malvidin [20-25]. The seeds of $S$. cumini were claimed to contain alkaloid, jambosine, glycoside jambolin, and ellagic acid [26]. The seeds have been reported to be rich in flavonoids [27]. Daulatabad et al. [28] reported the presence of epoxy and cyclopropenoid fatty acids in S. cumini seed oil. The leaves are rich in acylated flavonol glycosides, quercetin, myricetin, myricitin, myricetin-3-0-4-acetyl-L-rhamnopyranoside, triterpenoids, esterase, galloyl carboxylase, and tannin [29-32]. Kumar et al. [33] have evaluated the phytochemical composition of the leaf oil of $S$. cumini. The stem bark is rich in betulinic acid, friedelin, epifriedelanol, betasitosterol, eugenin, terpenoids and fatty acid ester of epifriedelanol [34],

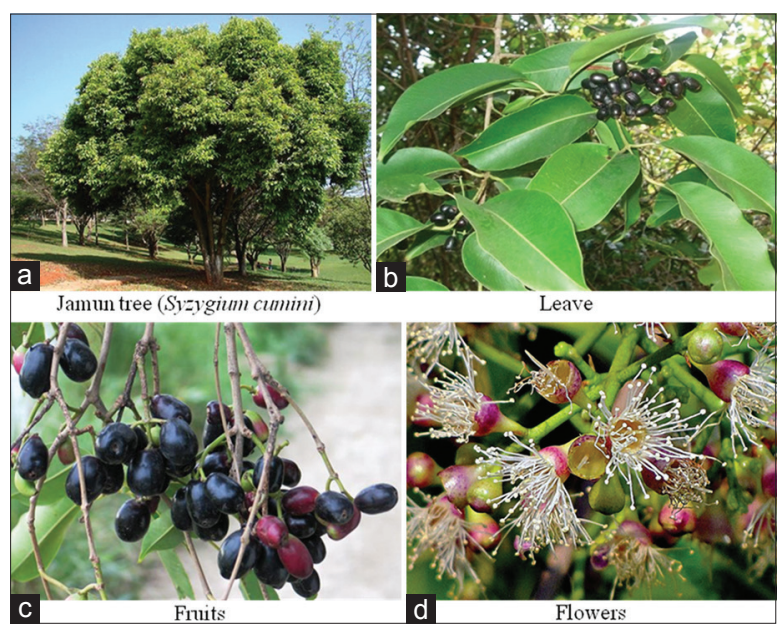

Fig. 1: (a-d) Morphology of leaf, flower, and fruits of jamun tree quercetin kaempferol, myricetin, gallic acid and ellagic acid [35], bergenins [36], flavonoids and tannins [37]. The phytoconstituents of S. cumini flowers were analyzed by Nair and Subramanian [38]. The presence of flavonoid glucosides, such as isorhamnetin 3-0-rutinoside, was reported in the roots of $S$. cumini $[39,40]$.

Even though, several research studies have been carried out to evaluate the antidiabetic potential of $S$. cumini and also various phytochemical compounds were reported in different parts of jamun tree, no information available on molecular mechanism for their anti-diabetic action. Hence, in this study, an attempt has been made to decipher the interaction between phytochemical compounds of jamun tree with key carbohydrate digestive enzyme ( $\alpha$-amylase) using Autodock software.

\section{METHODS}

\section{Preparation of protein receptor}

The pancreatic $\alpha$-amylase structure was downloaded from protein database (Ref. 4X9Y). It was a wild type human pancreatic $\alpha$-amylase at true atomic resolution $(1.07 \mathrm{~A})$ as reported by Caner and Brayer in 2014 by X-ray diffraction study. All water molecules were removed, hydrogen atoms were added, non-polar hydrogen atoms were merged, and Gasteiger charge was assigned to the receptor molecule.

\section{Preparation of ligands}

The major phytochemical compounds of $S$. cumini such as citric acid, malic acid, gallic acid, delphinidin-3-gentiobioside, malvidin3-laminaribioside, petunidin-3-gentiobioside, cyanidin diglucoside, petunidin, malvidin, ellagic acid, quercetin, myricetin, myricetin-3-04-acetyl-L-rhamnopyranoside, betulinic acid, friedelin, epifriedelanol, beta-sitosterol, eugenin, kaempferol, bergenins, and isorhamnetin 3-0-rutinoside were used as ligands (Table 1; Figs. 2 and 3). The 3D structure of each ligand was obtained from Pubchem and finally converted into PDF files using Open Babel.

\section{Docking study}

Automated molecular docking study was conducted with Autodock 4.2.6 (Scripps Research Institute, La Jolla, CA). The root of each ligand was detected, and torsion angles were identified for ten independent runs per ligand. A grid box of $126 \times 100 \times 96$ points in $\mathrm{x}, \mathrm{y}$ and $\mathrm{z}$ directions was built with a grid spacing of $0.575 \mathrm{~A}^{\circ}$ for amylase macromolecule. The default settings were used for all other Autodocking parameters. At the end of docking, the best poses were analyzed for binding free energy (kcal/mol), docking predicted inhibition constant (Ki), intermolecular

Table 1: Molecular characteristics of different phytochemical compounds of jamun tree

\begin{tabular}{|c|c|c|c|c|}
\hline S. No. & Name of the phytochemical & $\begin{array}{l}\text { Number of non-polar } \\
\text { hydrogen atoms }\end{array}$ & $\begin{array}{l}\text { Number of aromatic } \\
\text { carbons }\end{array}$ & $\begin{array}{l}\text { Number of rotatable } \\
\text { bonds }\end{array}$ \\
\hline 1 & Berginin & 11 & 6 & 7 \\
\hline 2 & Beta-sitosterol & 49 & 0 & 7 \\
\hline 3 & Betulinic acid & 46 & 0 & 4 \\
\hline 4 & Citric acid & 4 & 0 & 9 \\
\hline 5 & Cyanidine diglycoside & 20 & 15 & 18 \\
\hline 6 & Delphinidin-3-gentiobioside & 19 & 15 & 19 \\
\hline 7 & Ellagic acid & 2 & 12 & 4 \\
\hline 8 & Epifriedelanol & 51 & 0 & 1 \\
\hline 9 & Eugenin & 9 & 9 & 2 \\
\hline 10 & Friedelin & 50 & 0 & 0 \\
\hline 11 & Gallic acid & 2 & 6 & 5 \\
\hline 12 & Kaempferol & 6 & 15 & 5 \\
\hline 13 & Malic acid & 3 & 0 & 6 \\
\hline 14 & Malvidin & 11 & 15 & 7 \\
\hline 15 & Malvidin-3-laminaribioside & 25 & 15 & 19 \\
\hline 16 & Myricetin & 4 & 15 & 7 \\
\hline 17 & Myricetin-3-0-4-acetyl-L-rhamnopyranoside & 15 & 15 & 12 \\
\hline 18 & Petunidin & 8 & 15 & 7 \\
\hline 19 & Petunidin-3-gentiobioside & 22 & 25 & 19 \\
\hline 20 & Quercetin & 5 & 15 & 6 \\
\hline 21 & Acarbose & 29 & 0 & 32 \\
\hline
\end{tabular}




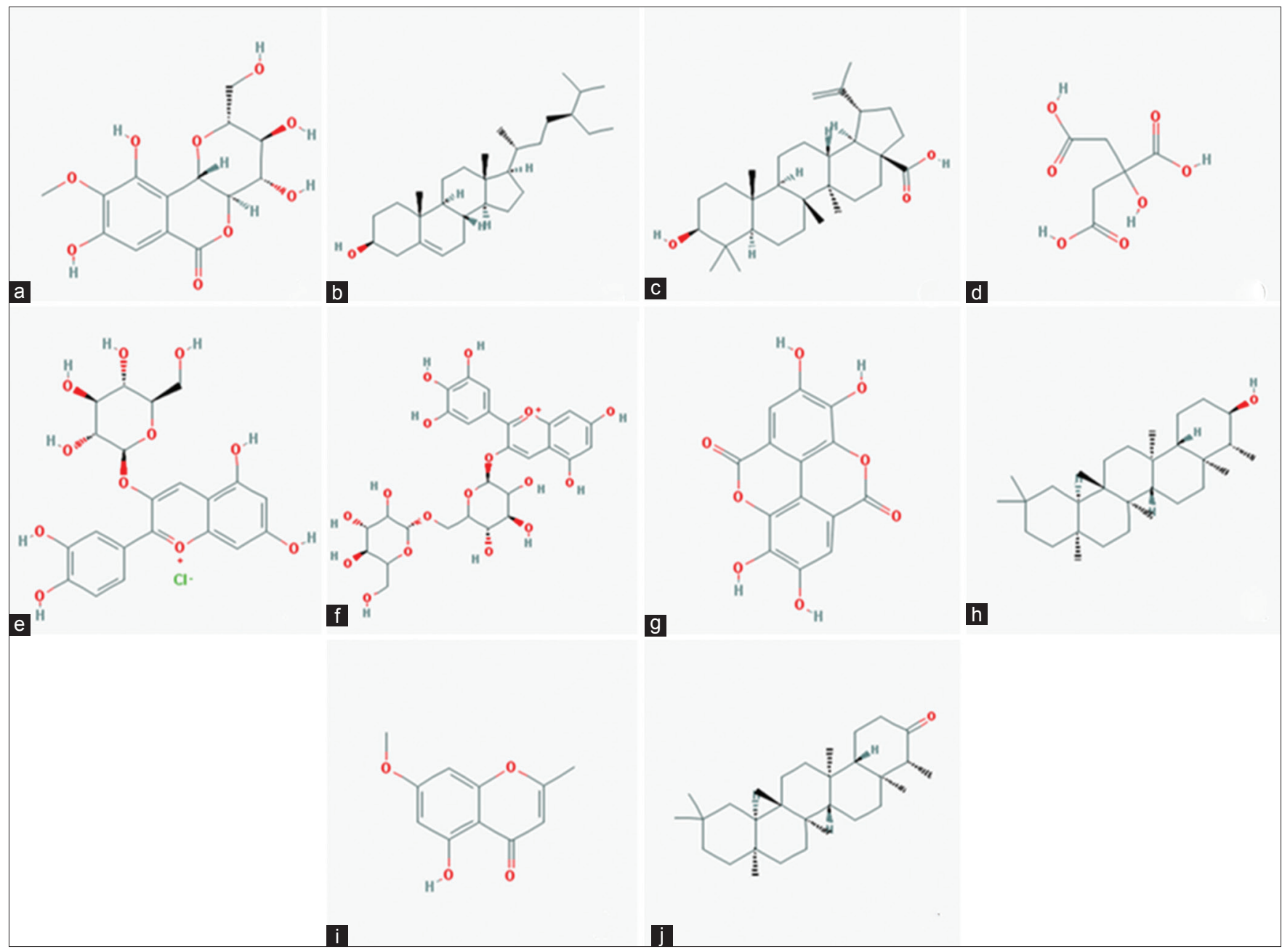

Fig. 2: Structure of phytochemical constituents of jamun tree: Berginin (a), beta-sitosterol (b), betulinic acid (c), citric acid (d), cyanidin diglucoside (e), delphinidin-3-gentiobioside (f), ellagic acid (g), epifriedelanol (h), eugenin (i), and friedelin (j)

energy, internal energy, torsional energy, root mean square and number of $\mathrm{H}$ bonds formed were recorded, and the molecular interaction images were visualized using Chimera software.

\section{RESULTS AND DISCUSSION}

Antidiabetic effect of jamun tree parts was deeply studied in previous research projects. Jamun seed kernel aqueous extract significantly prevented hyperglycemia and hyperinsulinemia-induced by high fructose diet induced experimental animals [41]. Type 2 diabetic individuals consuming seed kernel extract showed a decrease in serum glucose level [42]. Chaturvedi et al. [43] reported that blood glucose level remained stable in mild diabetic rats after STZ administration and showed antihyperglycemic effect on the $10^{\text {th }}$ day. Aqueous and alcoholic extracts and lyophilized powder of kernels in diabetic animals showed significant antihyperglycemic activity in mild to moderate degree of hyperglycemia [44]. Fruit aqueous extract caused a marginal reduction in plasma glucose levels in diabetic mice [45]. The fruit pulp ethanolic extract produced a good effect in both mild and severe diabetic animals and $100 \mathrm{mg} / \mathrm{kg}$ body weight of water extract showed maximum effect [46]. Reduction of glycemia was observed after 7 days treatment with the ethanolic, aqueous and butanolic fractions of leaf [47]. In another study, administration of 20 and $40 \mathrm{mg} / \mathrm{kg}$ of ethanolic leaf extract exhibited significant results in normal and hyperglycemic adult rabbits [48]. The antidiabetic activity of hydroalcoholic extracts of $S$. cumini leaves was noticed by Shankar and Suthakaran [49]. Aqueous extract of stem bark showed a significant decrease in serum glucose levels in alloxan-induced diabetic rats [50]. Methanolic extract of stem bark decreased the blood glucose levels in mice [51].
Molecular interaction of phytochemical constituents of jamun tree with $\alpha$-amylase enzyme has been investigated in this study using Autodock software, and the results are given in Table 2 and Figs. 4 and 5. When compared to the synthetic drug acarbose $(-2.43 \mathrm{kcal} / \mathrm{mol})$, phytochemicals like friedelin $(-9.54 \mathrm{kcal} / \mathrm{mol})$, epifriedelanol $(-8.98 \mathrm{kcal} / \mathrm{mol})$, betulinic acid $(-8.60 \mathrm{kcal} / \mathrm{mol})$, beta-sitosterol $(-8.56 \mathrm{kcal} / \mathrm{mol})$, petunidin-3-gentiobioside $(-7.52$ $\mathrm{kcal} / \mathrm{mol})$, kaempferol $(-7.08 \mathrm{kcal} / \mathrm{mol})$, petunidin $(-6.21 \mathrm{kcal} / \mathrm{mol})$, quercetin $(-6.03 \mathrm{kcal} / \mathrm{mol})$, myricetin $(-5.80 \mathrm{kcal} / \mathrm{mol})$ and berginin $(-5.27 \mathrm{kcal} / \mathrm{mol})$ were exhibited remarkable interaction with $\alpha$-amylase at lower energy level. This indicates, the phytoconstituents of jamun tree could inhibit $\alpha$-amylase in a more efficient way even with low binding energy than the synthetic compound acarbose. The results obtained from the present investigation given significant information that the phytochemicals of jamun tree could work better with the diabetic targets by binding with $\alpha$-amylase and slows down the starch digestion and leads to slow release of glucose in the blood stream. Due to this mechanism, the jamun fruit seeds could control the blood sugar level more effectively. Hence, we could take some leads from phytochemicals of jamun tree towards the development/synthesis of $\alpha$-amylase inhibitors for the management of diabetic patients.

The results of this study were supported by earlier research regarding the anti-diabetic activity of selected phytochemicals of jamun tree. Bergenin was isolated from the roots of Caesalpinia digyna and evaluated for antidiabetic (type 2) activity in streptozotocin (STZ)nicotinamide-induced diabetic rats [52]. Antidiabetic and antioxidant potential of $\beta$-sitosterol isolated from Solanum surattense was evaluated 


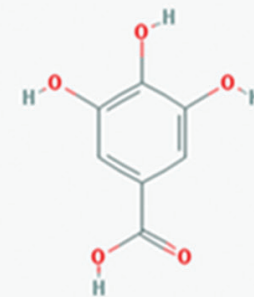

a

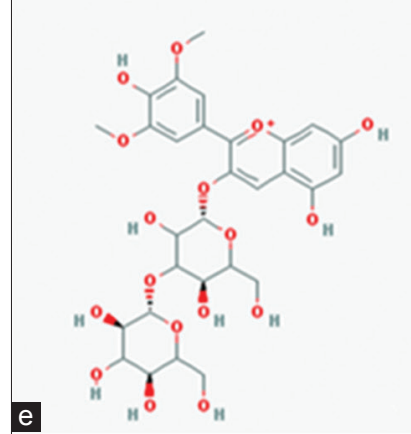<smiles></smiles><smiles>O=C(O)CC(O)COCCO</smiles>

b<smiles>O=c1c(O)c(-c2cc(O)c(O)c(O)c2)oc2cc(O)cc(O)c12</smiles>

f
C

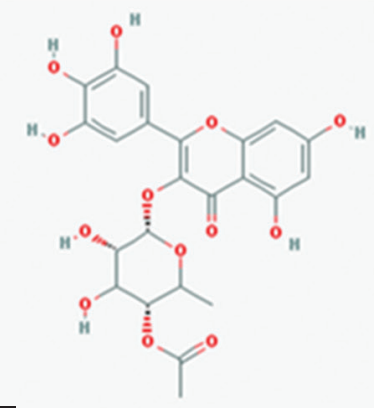

g<smiles>COc1cc(-c2cc3cc(O)cc(O)c3cc2O[C@@H]2O[C@H](CO[C@H]3O[C@H](CO)[C@@H](O)[C@H](O)[C@H]3O)[C@@H](O)[C@H](O)[C@H]2O)cc(O)c1O</smiles>

d

h<smiles></smiles><smiles></smiles>

Fig. 3: Structure of phytochemical constituents of jamun tree: Gallic acid (a), kaempferol (b), malic acid (c), malvidin (d), malvidin-3laminaribioside (e), myricetin (f), myricetin-3-o-4-acetyl-1-rhamnopyranoside (g), petunidin (h), petunidin-3-gentiobioside (i) and quercetin (j)

Table 2: Molecular docking results of $\alpha$-amylase with different phytochemical compounds of jamun tree

\begin{tabular}{|c|c|c|c|c|c|c|c|c|}
\hline $\begin{array}{l}\text { S. } \\
\text { No. }\end{array}$ & Name of the ligand & $\begin{array}{l}\text { Binding } \\
\text { free energy } \\
\text { (kcal/mol) }\end{array}$ & $\begin{array}{l}\text { Docking predicted } \\
\text { inhibition } \\
\text { constant (Ki) }\end{array}$ & $\begin{array}{l}\text { Intermolecular } \\
\text { energy }\end{array}$ & $\begin{array}{l}\text { Internal } \\
\text { energy }\end{array}$ & $\begin{array}{l}\text { Torsional } \\
\text { energy }\end{array}$ & RMS & $\begin{array}{l}\text { Number of } \mathrm{H} \\
\text { bonds formed }\end{array}$ \\
\hline 1 & Berginin & -5.27 & $136.98 \mathrm{uM}$ & -7.36 & -3.59 & 2.09 & 42.99 & 3 \\
\hline 2 & Beta-sitosterol & -8.56 & $527.25 \mathrm{nM}$ & -10.65 & -0.88 & 2.09 & 43.16 & 2 \\
\hline 3 & Betulinic acid & -8.60 & $500.92 \mathrm{nM}$ & -9.79 & -0.44 & 1.19 & 54.83 & 3 \\
\hline 4 & Citric acid & -3.20 & $4.55 \mathrm{mM}$ & -5.88 & -3.01 & 2.68 & 51.25 & 3 \\
\hline 5 & Cyanidine diglycoside & -3.92 & $1.33 \mathrm{mM}$ & -9.29 & -8.34 & 5.37 & 33.32 & 7 \\
\hline 7 & Ellagic acid & -6.69 & $12.52 \mathrm{uM}$ & -7.88 & -2.07 & 1.19 & 55.44 & 4 \\
\hline 8 & Epifriedelanol & -8.98 & $260.67 \mathrm{nM}$ & -9.28 & 0.03 & 0.3 & 44.61 & 2 \\
\hline 9 & Eugenin & -5.48 & $96.88 \mathrm{uM}$ & -6.07 & -0.75 & 0.6 & 53.51 & 1 \\
\hline 10 & Friedelin & -9.54 & $102.15 \mathrm{nM}$ & -9.54 & 0 & 0 & 45.66 & 1 \\
\hline 11 & Gallic acid & -4.60 & $421.71 \mathrm{uM}$ & -6.1 & -1.75 & $1 / 49$ & 66.71 & 3 \\
\hline 12 & Kaempferol & -7.08 & $6.47 \mathrm{uM}$ & -8.57 & -1.51 & 1.49 & 51.74 & 2 \\
\hline 13 & Malic acid & -3.14 & $4.98 \mathrm{mM}$ & -4.93 & -3.06 & 1.79 & 65.26 & 1 \\
\hline 14 & Malvidin & -5.98 & $41.23 \mathrm{uM}$ & -8.07 & -1.19 & 2.09 & 45.4 & 2 \\
\hline 17 & $\begin{array}{l}\text { Myricetin-3-0-4-acetyl-L- } \\
\text { rhamnopyranoside }\end{array}$ & -3.69 & $1.98 \mathrm{mM}$ & -7.27 & -7.36 & 3.58 & 33.78 & 2 \\
\hline 18 & Petunidin & -6.21 & $27.88 \mathrm{uM}$ & -8.3 & -1.1 & 2.09 & 49.87 & 3 \\
\hline 19 & Petunidin-3-gentiobioside & -7.52 & $3.06 \mathrm{uM}$ & -13.19 & 32.56 & 5.67 & 65.73 & 1 \\
\hline 20 & Quercetin & -6.03 & $37.74 \mathrm{uM}$ & -7.82 & -2.87 & 1.79 & 45.61 & 1 \\
\hline 21 & Acarbose & -2.43 & $16.58 \mathrm{mM}$ & -8.99 & -10.52 & 6.56 & 39.08 & 4 \\
\hline
\end{tabular}

RMS: Root mean square 


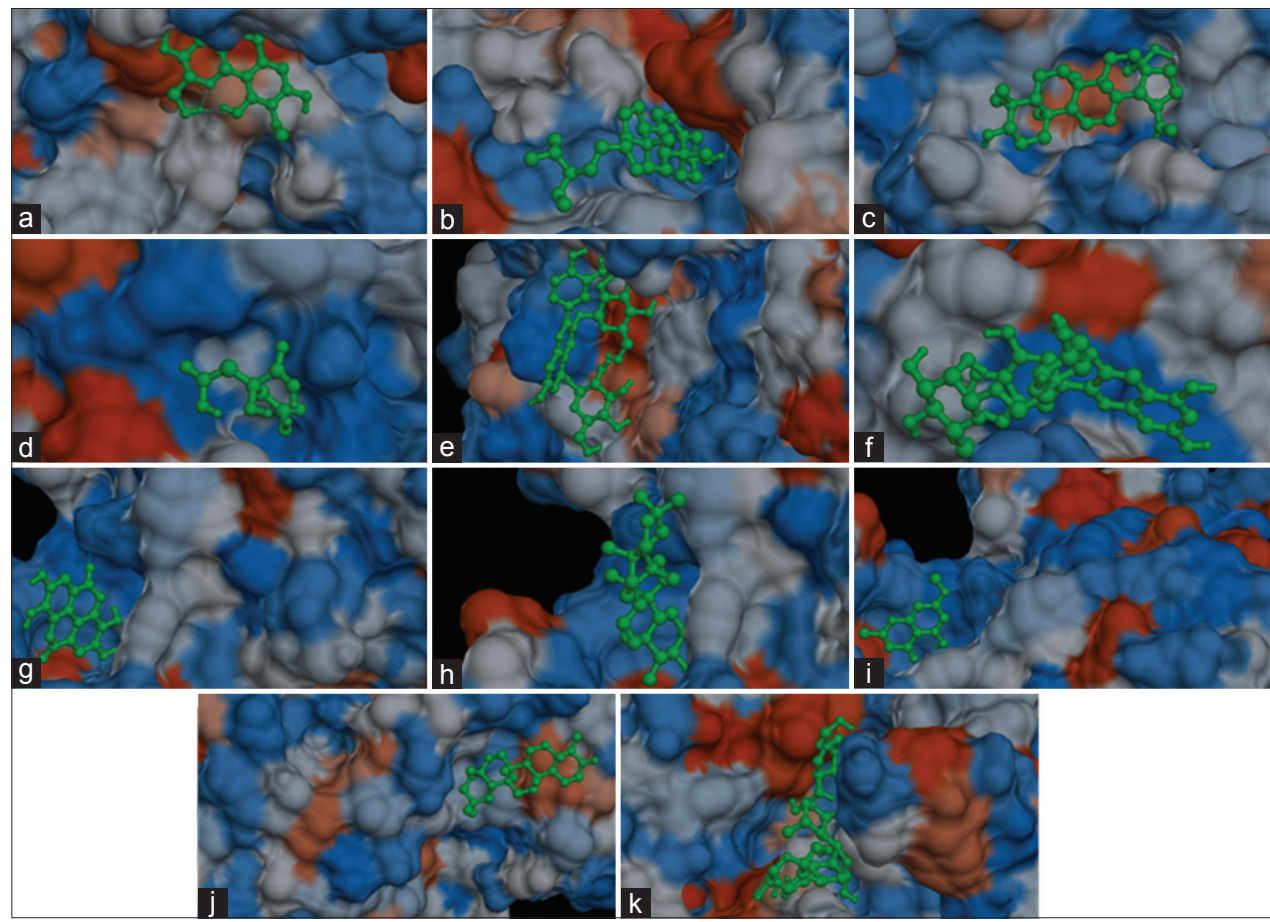

Fig. 4: Docking images showing the interaction of berginin (a), beta-sitosterol (b), betulinic acid (c), citric acid (d), cyanidine diglycoside (e), delphinidin-3-gentiobioside (f), ellagic acid (g), epifriedelanol (h), eugenin (i), friedelin (j) and acarbose (k) with $\alpha$-amylase

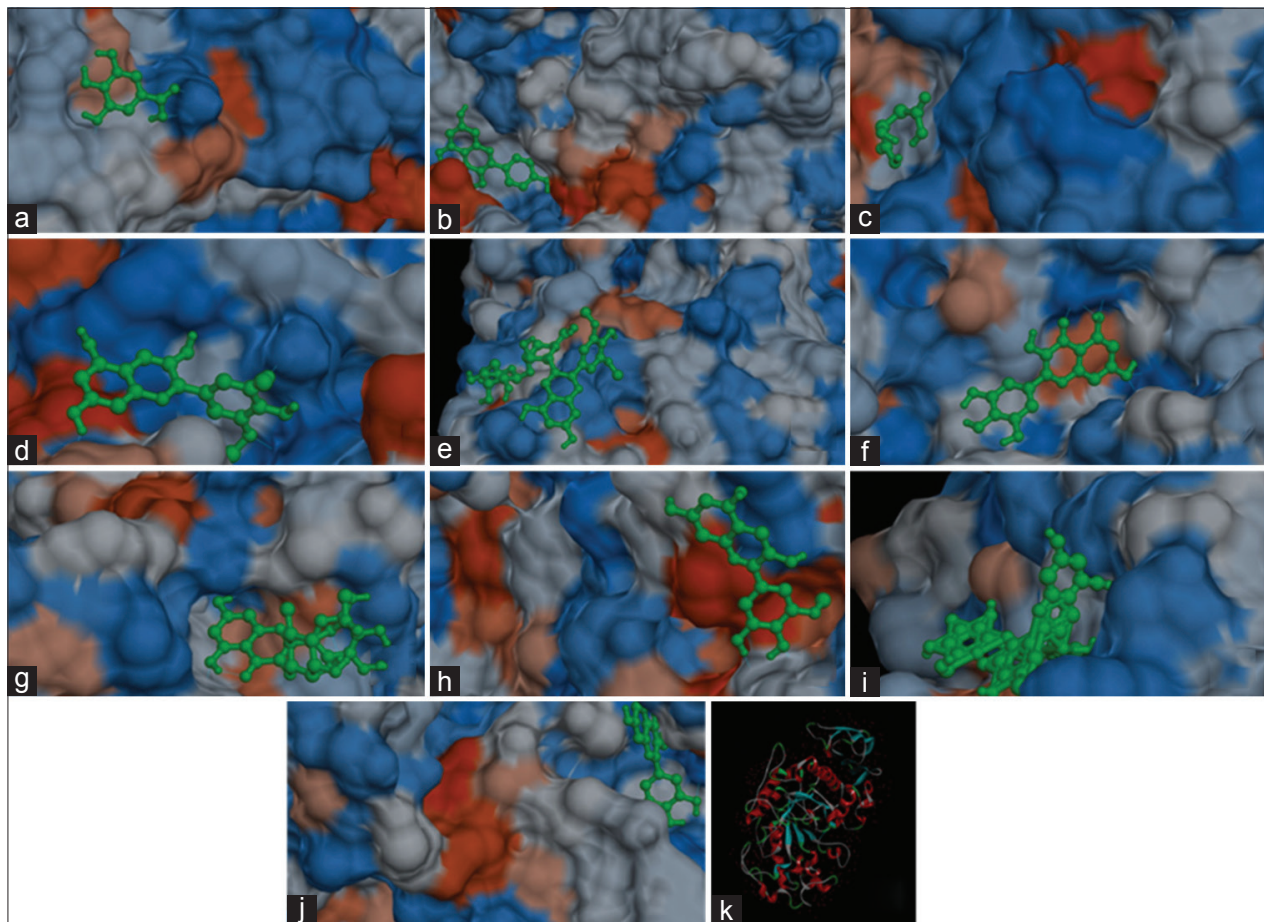

Fig. 5: Docking images showing the interaction of gallic acid (a), kaempferol (b), malic acid (c), malvidin (d), malvidin-3-laminaribioside (e), myricetin (f), myricetin-3-o-4-acetyl-1-rhamnopyranoside (g), petunidin (h), petunidin-3-gentiobioside (i) and quercetin (j) with $\alpha$-amylase (k)

in STZ-induced diabetic rats [53]. Betulinic acid from Dillenia indica was reported to exhibit $47.4 \% \alpha$-amylase inhibition and significant antidiabetic activity in STZ-nicotinamide induced diabetic mice at the dose of $10 \mathrm{mg} / \mathrm{kg}$ [54]. Uddin et al. [55] showed $\alpha$-amylase inhibitory activity and hypoglycemic activity of Citrus macroptera fruit containing citric acid in hyperglycemic rats. Structure-activity relationship of cyanidin and its glycosides to inhibit pancreatic $\alpha$-amylase was investigated under in vitro conditions [56]. Delphinidin-3-rutinoside was reported to stimulates glucagon-like peptide-1 secretion in Murine GLUTag cell line via the $\mathrm{Ca} 2+/$ calmodulin-dependent kinase II pathway, and this mechanism is effective for controlling blood glucose levels in type 2 diabetic patients [57].

Fatima et al. [58] reported that the ellagic acid in Emblica officinalis exerts antidiabetic activity through the action on $\beta$-cells of pancreas. Gallic acid can increase GLUT4 translocation and glucose uptake 
activity in an Akt-independent but wortmannin-sensitive manner [59]. Antidiabetic activity of kaempferol and its glycoside-rich fraction isolated from soybean leaf was evaluated in genetically type 2 diabetic mice [60]. Possible hypoglycemic effect in type 2 diabetic patients by Aloe vera high molecular weight fractions with malic acid was explained by Yagi et al. [61]. Antidiabetic and pancreatic regeneration potential of aerial parts of Clitoria ternatea containing Malvidin were reported [62]. Therapeutic potential of myricetin in diabetes mellitus was reviewed by Li and Ding [63]. Inhibitory effects of muscadine anthocyanins including petunidin on $\alpha$-glucosidase were investigated by You et al. [64]. Intra-peritoneal injection of quercetin in STZ-induced diabetic rats significantly and dose-dependently decreased the plasma glucose level [65].

\section{CONCLUSION}

Interaction of phytochemical compounds of jamun tree with a well-known diabetic target $\alpha$-amylase was revealed by the present study. Some of the phytochemical constituents such as friedelin, epifriedelanol, betulinic acid, beta-sitosterol, petunidin, kaempferol, quercetin, myricetin, and berginin can bind more effectively than the synthetic drug acarbose and inhibit the activity of $\alpha$-amylase enzyme and thus slows down the glucose release in blood stream. Hence, the results of the present investigation offer scientific evidence for the antidiabetic potential of jamun tree parts by elucidating the mechanism of action shown by its bioactive principles. The chemical constituents of jamun tree with high potential to inhibit $\alpha$-amylase could be chosen as a lead for further study and chemical synthesis as anti-diabetic agents for the management of type 2 diabetic patients.

\section{ACKNOWLEDGMENTS}

Authors are thankful to the Honorable Vice Chancellor of SASTRA University for his constant encouragement and support to carry out this research work.

\section{REFERENCES}

1. Eichler HG, Korn A, Gasic S. The effect of a new specific $\alpha$-amylase inhibitor on post-prandial glucose and insulin excursions in normal and Type 2 (non-insulin dependent) diabetic patients. Diabetol 1984;26:2781.

2. Patwardhan B, Vaidya AD, Chorghade M. Ayurveda and natural products drug discovery. Curr Sci 2004;86:789-99.

3. Grover JK, Yadav S, Vats V. Medicinal plants of India with anti-diabetic potential. J Ethnopharmacol 2002;81(1):81-100.

4. Mukherjee PK, Maiti K, Mukherjee K, Houghton PJ. Leads from Indian medicinal plants with hypoglycemic potentials. J Ethnopharmacol 2006;106(1):1-28.

5. Sagrawat H, Mann AS, Kharya MD. Pharmacological potential of Eugenia jambolana: A review. Pharmacogn Mag 2006;2:96-104.

6. Baliga MS, Bhat HP, Baliga BR, Wilson R, Palatty PL. Phytochemistry, traditional uses and pharmacology of Eugenia jambolana Lam. (black plum): A review. Food Res Int 2011;44:1776-89.

7. Shrotri DS, Kelkar M, Deshmukh VK, Aiman R. Investigations of the hypoglycemic properties of Vinca rosea, Cassia auriculata and Eugenia jambolana. Indian J Med Res 1963;51:464-7.

8. Lal BN, Choudhuri KD. Observations on Momordica charantia Linn, (Karvellaka) and Eugenia jambolana Lam. (Jamboo) as oral antidiabetic remedies. Indian J Med Res 1968;2:161.

9. Chirvan-Nia P, Ratsimamanga AR. Regression of cataract and hyperglycemia in diabetic sand rats (Psammomys obesus) having received an extract of Eugenia Jambolana (Lamarck). C R Acad Sci Hebd Seances Acad Sci D 1972;274(2):254-7.

10. Ashok P, Daradka MM. Antidiabetic activity of Syzygium cumini seed extracts in alloxan induced diabetic mice. Hamdard Med 2001:52:41-8.

11. Sharma SB, Nasir A, Prabhu KM, Murthy PS, Dev G. Hypoglycaemic and hypolipidemic effect of ethanolic extract of seeds of Eugenia jambolana in alloxan-induced diabetic rabbits. J Ethnopharmacol 2003;85(2-3):201-6.

12. Bhat G, Zinjarde SS, Bhargava SY, Ravi Kumar A, Joshi BN. Antidiabetic Indian plants: A good source of potent amylase inhibitors. Evid Based Complement Alternat Med 2011;2011:810207.

13. Bansal R, Ahmad N, Kidwai JR. Effects of oral administration of
Eugenia jambolana seeds \& chloropropamide on blood glucose level \& pancreatic cathepsin B in rat. Indian J Biochem Biophys 1981;18(5):377.

14. Singh N, Gupta M. Effects of ethanolic extract of Syzygium cumin (Linn) seed powder on pancreatic islets of alloxan diabetic rats. Indian J Exp Biol 2007;45(10):861-7.

15. Kohli KR, Singh RH. A clinical trial of Jambu (Eugenia jambolana) in non-insulin dependent diabetes mellitus. J Res Ayurveda Siddha 1993;14:89-97.

16. Yadav M, Lavania A, Tomar R, Prasad GB, Jain S, Yadav $H$ Complementary and comparative study on hypoglycemic and antihyperglycemic activity of various extracts of Eugenia jambolana seed, Momordica charantia fruits, Gymnema sylvestre, and Trigonella foenum graecum seeds in rats. Appl Biochem Biotechnol 2010;160(8):2388-400.

17. Modak M, Dixit P, Londhe J, Ghaskadbi S, Devasagayam TP. Indian herbs and herbal drugs used for the treatment of diabetes. J Clin Biochem Nutr 2007;40(3):163-73

18. Jana K, Ghosh A, Chatterjee K, Ghosh D. Antidiabetic activity of seed of Eugenia jambolana in streptozotocin induced diabetic male albino rat: An apoptotic and genomic approach. Int J Pharm Pharm Sci 2014;6:407-12.

19. Sinha SK, Ahmad I, Gayathri M. Antidiabetic effect of ethanol extract of Syzygium jambolanum seed (in vitro). Int J Drug Dev Res 2013;5:18791.

20. Venkateswarlu G. On the nature of the colouring matter of the jambul fruit (Eugenia jambolana). J Indian Chem Soc 1952;29:434-7.

21. Sharma JN, Seshadri TR. Survey of anthocyanins from Indian sources: Part II. J Sci Ind Res 1955;14:211-4.

22. Lewis YS, Dwarakanath CT, Johar DS. Acids and sugars in Eugenia jambolana. J Sci Ind Res 1956;15:280-1.

23. Jain MC, Seshadri TR. Anthocyanins of Eugenia jambolana fruits. J Chem 1975;3:20-3.

24. Vijayanand P, Rao LJ, Narasimham P. Volatile flavour components of jamun fruit (Syzygium cumini). J Nat Prod Chem 2001;16:47-9.

25. Veigas JM, Narayan MS, Laxman PM, Neelwarne B. Chemical nature stability and bioefficacies of anthocyanins from fruit peel of Syzygium cumini Skeels. Food Chem 2007;105:619-27.

26. Morton J. Fruits of Warm Climates. Miami: Julia Morton Winterville North Carolina; 1987. p. 375-8.

27. Ravi K, Ramachandran B, Subramanian S. Protective effect of Eugenia jambolana seed kernel on tissue antioxidants in streptozotocin induced diabetic rats. Biol Pharm Bull 2004;27(8):1212-7.

28. Daulatabad CM, Mirajkar AM, Hosamani KM, Mulla GM. Epoxy and cyclopropenoid fatty acids in Syzygium cumini seed oil. J Sci Food Agric 1988;43:91-4.

29. Gupta GS, Sharma DP. Triterpenoid and other constituents of Eugenia jambolana leaves. Phytochem 1974;13:2013-4.

30. Bhatia IS, Sharma SK, Bajaj KL. Esterase and galloyl carboxylase from Eugenia jambolana leaves. Indian J Exp Biol 1974;12:550-2.

31. Mahmoud II, Marzouk MS, Moharram FA, El-Gindi MR, Hassan AM. Acylated flavonol glycosides from Eugenia jambolana leaves. Phytochemistry 2001;58(8):1239-44.

32. Timbola AK, Szpoganicz B, Branco A, Monache FD, Pizzolatti MG. A new flavonol from leaves of Eugenia jambolana. Fitoterapia 2002;73(2):174-6.

33. Kumar A, Naqvi AA, Kahol AP, Tandon S. Composition of leaf oil of Syzygium cumini L. from North India. Indian Perfum 2004;48:439-41.

34. Sengupta P, Das PB. Terpenoids and related compounds. Part IV: Terpenoids in the stem bark of Eugenia jambolana Lam. Indian Chem Soc $1965 ; 42: 255-8$

35. Bhargava KK, Dayal R, Seshadri TR. Chemical components of Eugenia jambolana stem bark. Curr Sci 1974;43:645-6.

36. Kopanski L, Schnelle G. Isolation of bergenin from barks of Syzygium cumini. Planta Med 1988;54(6):572.

37. Bhatia IS, Bajaj KL. Chemical constituents of the seeds and bark of Syzygium cumini. Plant Med 1975;28(4):347-52.

38. Nair RA, Subramanian SS. Chemical examination of the flowers of Eugenia jambolana. J Sci Ind Res 1962;21:457-8.

39. Vaishnava MM, Gupta KR. Isorhamnetin 3-O-rutinoside from Syzygium cumini Lam. J Indian Chem Soc 1990;67:785-6.

40. Vaishnava MM, Tripathy AK, Gupta KR. Flavonoid glucosides from roots of Eugenia jambolana. Fitoterapia, 1992;63:259-60.

41. Vikrant V, Grover JK, Tandon N, Rathi SS, Gupta N. Treatment with extracts of Momordica charantia and Eugenia jambolana prevents hyperglycemia and hyperinsulinemia in fructose fed rats. J Ethnopharmacol 2001;76(2):139-43. 
42. Safdar M, Habibullah Khan A. Effect of jaman fruit extract on serum glucose and lipid profile in Type 2 diabetic individuals. Pak J Nutr 2006;5:573-6

43. Chaturvedi A, Bhawani G, Agarwal PK, Goel S, Singh A, Goel RK. Antidiabetic and antiulcer effects of extract of Eugenia jambolana seed in mild diabetic rats: Study on gastric mucosal offensive acid-pepsin secretion. Indian J Physiol Pharmacol 2009;53(2):137-46.

44. Achrekar S, Kaklij GS, Pote MS, Kelkar SM. Hypoglycemic activity of Eugenia jambolana and Ficus bengalensis: Mechanism of action. In Vivo 1991;5(2):143-7.

45. Grover JK, Vats V, Rathi SS, Dawar R. Traditional Indian anti-diabetic plants attenuate progression of renal damage in streptozotocin induced diabetic mice. J Ethnopharmacol 2001;76(3):233-8.

46. Sharma SB, Nasir A, Prabhu KM, Murthy PS. Antihyperglycemic effect of the fruit-pulp of Eugenia jambolana in experimental diabetes mellitus. J Ethnopharmacol 2006;104(3):367-73.

47. Oliveira AC, Endringer DC, Amorim LA, das Graças L Brandão M, Coelho MM. Effect of the extracts and fractions of Baccharis trimera and Syzygium cumini on glycaemia of diabetic and non-diabetic mice. J Ethnopharmacol 2005;102(3):465-9.

48. Arbab AG, Akhtar T, Rab F. Hypoglycaemic activity of Eugenia jambolana leaves. Pak J Nutr 1989;28:121-35.

49. Shankar M, Suthakaran R. Anti-diabetic activity of hydroalcoholic extract of Eugenia jambolana leaves in alloxan induced diabetic rats. Int J Pharm Pharm Sci 2014;6:138-40.

50. Schossler DR, Mazzanti CM, Almeida da Luzi SC, Filappi A, Prestes D, Ferreria da Silveira A, et al. Syzygium cumini and the regeneration of insulin positive cells from the pancreatic duct. Braz J Vet Res Anim Sci 2004;41:236-9.

51. Villaseñor IM, Lamadrid MR. Comparative anti-hyperglycemic potentials of medicinal plants. J Ethnopharmacol 2006;104(12):129-31.

52. Kumar R, Patel DK, Prasad SK, Laloo D, Krishnamurthy S, Hemalatha S. Type 2 antidiabetic activity of bergenin from the roots of Caesalpinia digyna rottler. Fitoterapia 2012;83(2):395-401.

53. Gupta R, Sharma AK, Dobhal MP, Sharma MC, Gupta RS. Antidiabetic and antioxidant potential of $\beta$-sitosterol in streptozotocin-induced experimental hyperglycemia. J Diabetes 2011;3(1):29-37.

54. Kumar S, Kumar V, Prakash O. Enzymes inhibition and antidiabetic effect of isolated constituents from Dillenia indica. Biomed Res Int 2013;2013:382063.

55. Uddin N, Hasan MR, Hossain MM, Sarker A, Hasan AH, Islam AF, et al. In vitro $\alpha$-amylase inhibitory activity and in vivo hypoglycemic effect of methanol extract of Citrus macroptera Montr. fruit. Asian Pac J Trop Biomed 2014;4(6):473-9.

56. Akkarachiyasit S, Charoenlertkul P, Yibchok-Anun S, Adisakwattana S. Inhibitory activities of cyanidin and its glycosides and synergistic effect with acarbose against intestinal $\alpha$-glucosidase and pancreatic $\alpha$-amylase. Int J Mol Sci 2010;11(9):3387-96.

57. Kato M, Tani T, Terahara N, Tsuda T. The anthocyanin delphinidin 3-rutinoside stimulates glucagon-like peptide-1 secretion in murine Glutag cell line via the $\mathrm{Ca}_{2} /$ calmodulin-dependent kinase ii pathway. PLoS One 2015;10(5):e0126157.

58. Fatima N, Hafizur RM, Hameed A, Ahmed S, Nisar M, Kabir N. Ellagic acid in Emblica officinalis exerts anti-diabetic activity through the action on $\beta$-cells of pancreas. Eur J Nutr 2015;136:1456-60.

59. Prasad CN, Anjana T, Banerji A, Gopalakrishnapillai A. Gallic acid induces GLUT4 translocation and glucose uptake activity in 3T3-L1 cells. FEBS Lett 2010;584(3):531-6.

60. Zang Y, Sato H, Igarashi K. Anti-diabetic effects of a kaempferol glycoside-rich fraction from unripe soybean (Edamame, Glycine max L. Merrill. "Jindai") leaves on KK-A(y) mice. Biosci Biotechnol Biochem 2011;75(9):1677-84

61. Yagi A, Hegazy S, Kabbash A, Wahab EA. Possible hypoglycemic effect of Aloe vera L. high molecular weight fractions on Type 2 diabetic patients. Saudi Pharm J 2009;17(3):209-15.

62. Verma PR, Itankar PR, Arora SK. Evaluation of antidiabetic antihyperlipidemic and pancreatic regeneration, potential of aerial parts of Clitoria ternatea. Rev Bras Farmacogn 2013;23:819-29.

63. Li Y, Ding Y. Therapeutic potential of myricetin in diabetes mellitus. Food Sci Hum Wellness 2012;1:19-25.

64. You Q, Chen F, Wang X, Luo PG, Jiang Y. Inhibitory effects of muscadine anthocyanins on $\alpha$-glucosidase and pancreatic lipase activities. J Agric Food Chem 2011;59(17):9506-11.

65. Vessal M, Hemmati M, Vasei M. Antidiabetic effects of quercetin in streptozocin-induced diabetic rats. Comp Biochem Physiol C Toxicol Pharmacol 2003;135C(3):357-64 